\title{
Synthesis and immunological evaluation of a low molecular weight saccharide with TLR-4 agonist activity
}

\author{
Vikram Basava, ${ }^{\mathrm{a}}$ Heather Romlein, ${ }^{\mathrm{b}}$ Constantine Bitsaktsis, ${ }^{\mathrm{b}}$ and Cecilia H. Marzabadi ${ }^{\mathrm{a} *}$ \\ ${ }^{a}$ Department of Chemistry \& Biochemistry, Seton Hall University, 400 South Orange Ave., South Orange, NJ 07079, USA \\ ${ }^{b}$ Department of Biological Science, Seton Hall University, 400 South Orange Ave., South Orange, NJ 07079, USA
}

\section{ARTICLE INFO}

\section{ABSTRACT}

\section{Article history:}

Received

Received in revised form

Accepted

Available online

\section{Keywords:}

agonist

LPS

Saccharide synthesis

TLR-4

Innate immunity
The paucity of FDA approved adjuvants renders the synthesis, characterization, and use of new compounds as vaccine adjuvants, a necessity. For this purpose, a novel saccharide analog has been synthesized from glucosamine, pyruvylated galactose and 1,4-cyclohexanediol and its biological efficacy was determined in innate immune cells. More specifically, we assessed the production of pro-inflammatory cytokines from the murine monocyte cell line, Raw 264.7 and from C57 BL/6 mouse peritoneal macrophages following exposure to the saccharide analog. Our data conclude that the novel saccharide has immunostimulatory activity on mouse macrophages as indicated by the elevated levels of IL-6 and TNF- $\alpha$ in culture supernatants. This effect was TLR-4-dependent but TLR-2-independent. Our data, suggest TLR-4 agonism; a key feature of vaccine adjuvants.

* Corresponding author. Tel.: +0-000-000-0000; fax: +0-000-000-0000; e-mail: author@university.edu 


\section{Introduction}

Vaccination is the only artificial way to prevent disease by eliciting robust, long-lived, and specific immune responses. Pathogenic proteins are important vaccine candidates due to their ability to stimulate both antibody and cell-mediated immunity. However, their frequent low immunogenicity can impact their efficacy as vaccine candidates. Also the use of "killed" pathogen particles results in an attenuated response versus vaccination with "live attenuated" particles.

The use of adjuvants is a promising approach to circumvent these problems but the restricted number of FDA-approved compounds renders the discovery of novel molecules very important. Adjuvants are compounds that enhance the specific immune response against co-inoculated antigens, ideally with minimal toxicity. Adjuvants have been used with vaccines since the $1920 \mathrm{~s}^{1}{ }^{1}$ The most common vaccine adjuvant that is still in use today is alum (aluminum phosphate or hydroxide). Both longterm and short term side effects associated with alum and other adjuvants has lead researchers to look for alternative molecules. ${ }^{2}$

In recent years, the adjuvanticity of many organic molecules, including polysaccharides and smaller carbohydrates, has been tested with variable outcomes. ${ }^{3}$ The notion of using carbohydrate recognition to foster an immune response comes from the important roles they play in nearly every aspect of the innate immune response. For example, surface carbohydrates of circulating foreign particles interact with a variety of immune receptors including pattern recognition receptors (PRRs) such as toll-like receptors (TLRs), and NOD-like receptors (nucleotidebinding oligomerization domain-like). ${ }^{4}$ PRRs recognize highly conserved structures called "pathogen associated molecular patterns" (PAMPs) that are on the surface of microorganisms such as bacteria and viruses. ${ }^{5}$ Examples of microbial PAMPs are lipopolysaccharide (LPS) from Gram-negative bacteria and peptidoglycan (PGN) from Gram positive organisms. PRRs help to destroy invading microorganisms mainly by triggering inflammatory responses upon activation by a PAMP. This response can lead to the release of cytokines and to the activation and maturation of T- and B-cells.

Whereas TLRs are located both inside and outside the cell membrane, NLRs are limited to the cytosol. The major cell surface TLRs that bind microbial components are TLR-4 (LPS) and TLR-2 (PGN) (either alone or in combination with TLR-1 or TLR-6). Collectively, TLRs are transmembrane proteins with a conserved intracellular Toll-interleulin1 receptor (TIR) domainresponsible for the induction of signal transduction following binding and an extracellular leucine-rich repeat (LRR) responsible for ligand binding. ${ }^{6}$ Signal transduction occurs following activation of TLRs through various effector proteins. TLR signaling induces the activation and maturation of APCs (antigen presenting cells) and the release of inflammatory cytokines such as TNF- $\alpha$ and IL- 6 . $^{7}$

A variety of molecules have been shown to bind to and activate TLRs on cells. These include analogs of naturallyoccurring bacterial ligands and a range of other structurally diverse compounds (Figure 1). ${ }^{8}$ Some of these TLR ligands have been utilized as successful vaccine adjuvants. ${ }^{9}$ As adjuvants, they target APCs, intermediates to both innate and adaptive immunity. Internalization of PAMPs by APCs and subsequent representation to naïve $\mathrm{T}$ cells leads to the differentiation to $\mathrm{T}$ cells with specific functions (e.g. Th1, Th2, Th17, Treg) $(\mathrm{Th}=$ helper $\mathrm{T}$ cells, Treg $=$ regulatory $\mathrm{T}$ cells). Signaling through TLR-4 leads to Th1 differentiation, whereas signaling through TLR-2/TLR-1 or TLR-2/TLR-6 favors Th2 responses. ${ }^{10}$
TLR-4 agonists are of particular interest to us due to the range of pathophysiological responses to TLR-4 binding, the diversity of known TLR-4 ligands (Figure 1), and the different types of molecular signals elicited by different TLR-4 agonists. ${ }^{11}$ Also, the mechanism of TLR-4 binding has been extensively studied and $\mathrm{x}$-ray structures of bound ligands have been determined. ${ }^{12}$

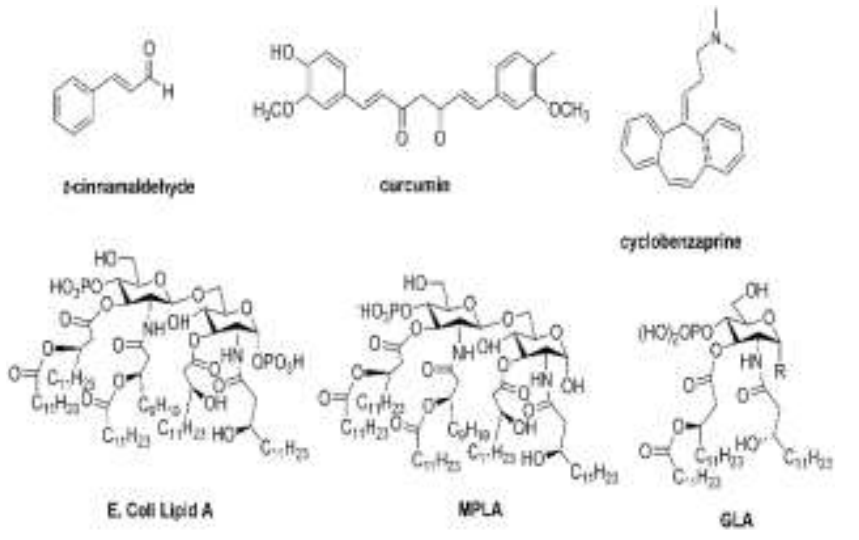

Figure 1. Diversity of TLR-4 ligands.

The activation of cells via LPS and its analogues has been shown to occur via a series of steps. ${ }^{12,36}$ First, the Lipid A portion of LPS binds to the LPS-binding protein (LBP). LBP is believed to help disaggregate LPS. Then, an LPS-LBP complex transfers monomeric LPS to CD14 (Cluster of Differentiation 14). CD14 delivers LPS to TLR-4. Binding of LPS to TLR-4 is assisted by the formation of an MD-2 (lymphocyte antigen 96)-TLR-4 complex. Two of the TLR-4-MD-2 complexes dimerize resulting in the activation of the toll-like receptor.

Binding of the two complexes leads to one of two paths of signaling; MyD88 (Myeloid differentiation primary response gene 88)-dependent or MyD88-independent pathways. When signaling occurs through the adaptor protein MyD88, a series of

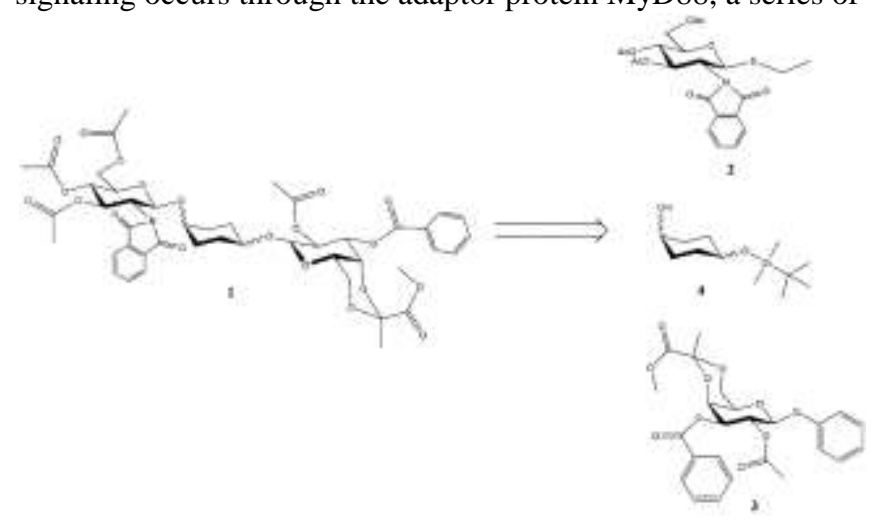

kinases are activated including mitogen-activated protein kinases (MAPKs) and nuclear factor-KB (NFKB). This ultimately leads to the production of pro-inflammatory cytokines. ${ }^{19,20}$ The latter pathway is based upon the TRIF and TRAM adaptor molecules that also leads to activation of IRF3 (Interferon Regulatory Factor 3) and to the production of Type I interferons. This stimulates dendritic cells (DCs) to express the co-stimulatory molecules CD40, CD80 and CD86 and this leads to T-cell maturation and differentiation. ${ }^{25}$

The modified Lipid A product from the LPS of Salmonella Minnesota R595, Monophosphoryl Lipid A (MPLA) (Figure 1), was the first TLR-4 agonist approved for human use as a vaccine adjuvant. ${ }^{13}$ It is currently utilized for both HPV and Hepatitis B vaccines in the United States. ${ }^{14,15}$ The reduced toxicity of MPLA has been attributed to the selective induction of the TLR-4-TRIF signaling pathway over the TLR-4-MyD88 pathway. ${ }^{16}$ Another 
smaller analog of Lipid A and MPLA, GLA (Glucopyranosyl Lipid A), is also being used as a vaccine adjuvant. ${ }^{17,18}$

Substantial efforts have been made to make other modified Lipid A analogues with an emphasis on both increasing the potency and reducing the toxicity of the molecules. The importance of the number and the type of alcohol and amine protecting groups has been well-established for the sugar-based TLR-4 ligands. Lipid A analogues that are not fully acylated have been shown to act as antagonists, rather than as agonists, for TLR- $4 .{ }^{21}$ This antagonism is believed to be due to the inability of TLR-4 to form a dimer with MD-2. This lack of dimer formation renders TLR-4 unresponsive.

Besides underacylated analogues, ether protection of Lipid A derivatives has also led to reduced TLR-4 signaling. ${ }^{22}$ To our knowledge, the effect of protection of Lipid A analogues as pyruvate ketals has not yet been described. This interesting residue has been found in the terminal chain in a variety of capsular polysaccharides including Streptococcus pneumonia, ${ }^{23}$ Klebsiella sp. ${ }^{24}$ and Bacteroides fragilis. ${ }^{25}$ In S. pneumoniae, the presence of a trans-3,4-pyruvate ketal in a galactopyranose residue is believed to impart resistance of the bacteria to reaction with antibodies to the capsular cell wall. ${ }^{23}$ In Klebsiella $s p$. and in $B$. fragilis the immunogenic pyruvate ketal moiety is located between $\mathrm{C} 4$ and $\mathrm{C} 6$ of the galactopyranose. ${ }^{24}$ Because of the occurrence of this residue across a spectrum of bacterial types, we wanted to investigate its ability to elicit and/or augment TLR4 agonism.

In this study, we prepared a small lipophilic molecule with properties that could potentially mimic those of known TLR-4 agonists such as Lipid A and MPLA. A cyclohexane diol was substituted for a central carbohydrate residue. Besides acyl protection, we incorporated a pyruvate ketal on a galactopyranose residue. The effects of our newly synthesized molecule and its precursors in models of innate and adaptive immunity were studied. Preliminary investigations into the mechanism of TLR activation were also conducted.

\section{Results and Discussion}

\subsection{Organic Synthesis of TLR ligand}

In designing a potential TLR-4 agonist, we believed it was important to retain the glucosamine moiety found in the molecules Lipid A and MPLA. However, instead of protecting the amino and alcohol functionalities as complex fatty acid derivatives, as in Lipid A, we opted for simple acetyl protection. Our analog 1 was prepared in multiple steps from three smaller units; two saccharide derivatives, $\mathbf{2}$ and $\mathbf{3}$, and a protected 1,4cyclohexane diol 4 (Figure 2). The diol spacer was utilized to connect glucosamine-derived sugar fragment $\mathbf{2}$ to galactose sugar fragment 3.

Figure 2. Retrosynthetic analysis for the preparation of analog 1

It was used as a "sugar surrogate" that would not require the multiple protection-deprotection steps, as would a central sugar moiety. Besides simple esterification, $\mathbf{3}$ was also protected at the

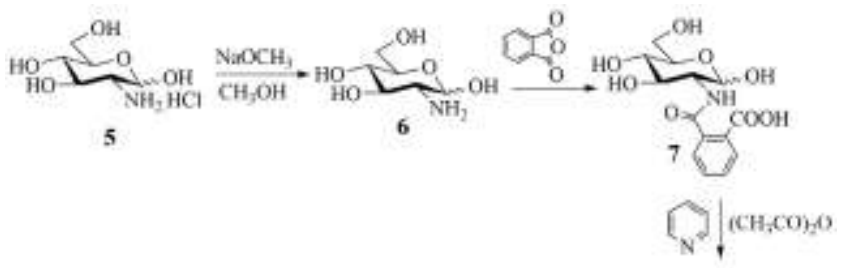

4- and 6-hydroxyl groups as a lipophilic pyruvate ester ketal. All pieces were coupled via thioglycoside donors using standard glycosylation conditions. ${ }^{26}$

For the synthesis of sugar subunit $\mathbf{2}$, the hydrochloride salt of glucosamine 5 was treated with sodium methoxide ${ }^{27}$ to give the free amino sugar $\mathbf{6}$ which was then treated with phthalic anhydride and acetic anhydride, in separate steps, to afford the peracetylated $N$-phthalimido protected glucosamine 8 in $50 \%$ overall yield (40\% of the desired $\beta$-anomer) (Scheme 1). ${ }^{28}$ Treatment of the anomeric acetate $\mathbf{8}$ with ethanethiol and boron trifluoride - diethyletherate gave $79 \%$ of the $\beta$-thioethyl glycosyl donor 2 . $^{26}$

\section{Scheme 1. Synthesis of donor 2.}

$\beta$-Thiophenyl glycoside $\mathbf{1 0}$ was synthesized from penta-Oacetyl-D-galactopyranose 9 by treatment with thiophenol and boron trifluoride - diethyletherate ( $84 \%$ yield) (Scheme 2$)^{26,29}$ Deacetylation of $\mathbf{1 0}$ with sodium methoxide and methanol produced $\mathbf{1 1}$ in quantitative yield. ${ }^{27}$ The 4,6-benzylidene 12 was then installed with benzaldehyde/zinc chloride, ${ }^{30}$ followed by the selective benzoylation of the $\mathrm{C} 3$ hydroxyl and the selective acetylation of the $\mathrm{C} 4-\mathrm{OH}$ group to give $\mathbf{1 4}$ (13\% over three steps). ${ }^{31}$ Treatment with trifluoroacetic acid, then methyl pyruvate, led to replacement of the 4,6-benzylidene functionality with the pyruvate ester ketal (36\% over 2 steps) and to the formation of $\mathbf{3}^{32}$

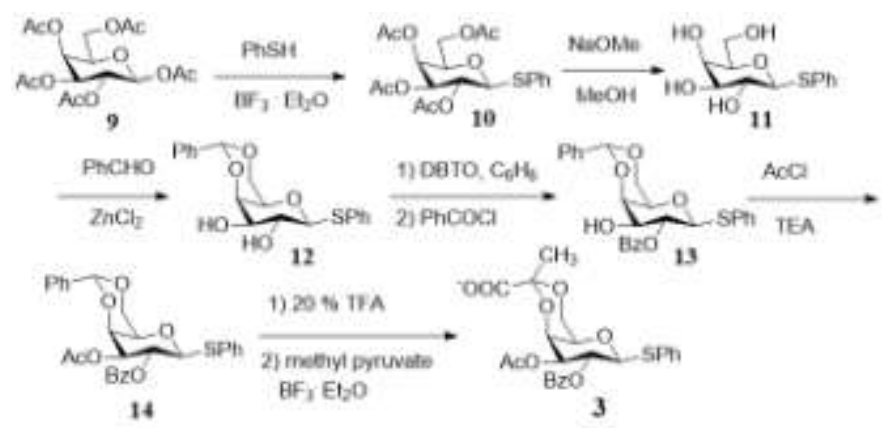

Scheme 2. Synthesis of donor 3

Reaction of cis,trans- 1,4-cyclohexanediol 15 with tertbutyldimethylsilyl chloride (1.25 equiv.) and imidazole (2.5 equiv. $)^{33}$ afforded a mixture of cis, trans- monosilylated diols. This mixture was chromatographically separated to give cis-3 as a single isomer (50\% yield) (Scheme 3). Treatment of sugar 1 with $N$-iodosuccinimide (NIS) and trimethylsilyl triflate in the presence of $\mathbf{3}$ afforded the cyclohexyl glycoside $\mathbf{1 7},{ }^{26}$ as well as some of the silylated cyclohexyl glycoside 16. The latter could be converted to the free alcohol $\mathbf{1 7}$ by treatment with tetra- $n$ butylammonium fluoride (TBAF) in THF. ${ }^{33}$ Overall conversion to 17 (either directly or via 16) was $65 \%$. Thiophenyl glycoside donor $\mathbf{3}$ was then coupled to the free hydroxyl of $17^{26}$ to give compound 1 in $58 \%$ yield. Both couplings afforded $\beta$-anomers in high yields and selectivities due to the presence of a participatory C2 ester group. ${ }^{34}$ 
cells.

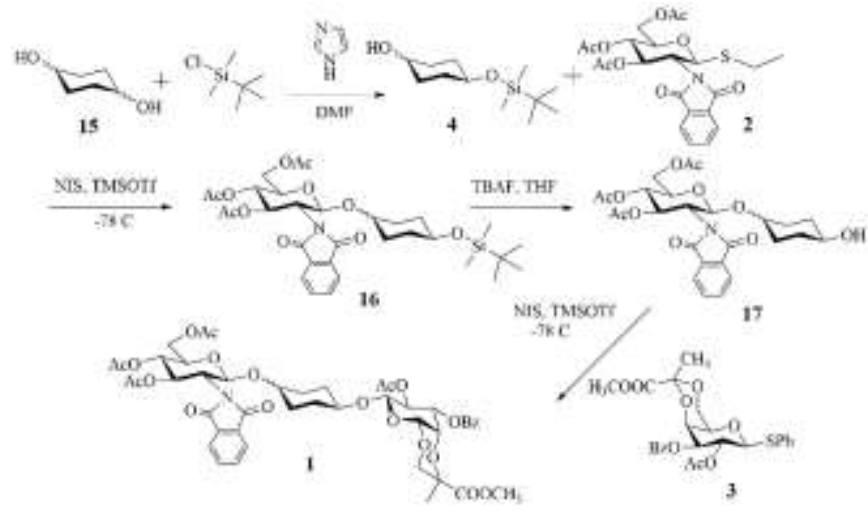

Scheme 3. Preparation of analog 1.

To summarize, compound $\mathbf{1}$ was synthesized in a straightforward manner from easily accessible starting materials. The sequence carried out (Schemes 1-3) uses known synthetic procedures to prepare and couple the different components. The yields ranged from modest to good for all steps in the synthesis. All compounds were characterized using NMR spectroscopy (1D and $2 \mathrm{D}$ proton and carbon) and by mass spectrometry (ESI).

\section{The novel, saccharide analog has pro-inflammatory properties on innate immune cells.}

Following the synthesis of our saccharide compound $\mathbf{1}$, we addressed its potential adjuvanticity by analyzing its proinflammatory properties on the murine monocyte/macrophage cell line, RAW 264.7, and on mouse (C57 BL/6) peritoneal exudate macrophages (PECs). For this purpose, both cell types were cultured with varying concentrations of the saccharide compound and at different time points supernatants were harvested. The IL- 6 and TNF- $\alpha$ cytokine concentrations in the supernatants were assessed by ELISA (Figure 3). The saccharide compound had an inflammatory effect on both RAW 264.7 cells and the PECs in terms of IL- 6 and TNF- $\alpha$ production. More specifically, IL-6 production was significantly increased at different saccharide concentrations after 48 hours of culture while a significant increase in TNF- $\alpha$ concentration was observed within 2 hours of culture (Figures $\mathbf{3 A}$ and $\mathbf{3 B}$, respectively).

Monosaccharides $\mathbf{2}$ and $\mathbf{3}$ were also evaluated separately for their ability to elicit pro-inflammatory cytokine production in mouse peritoneal macrophages. Both monosaccharides led to only modest increases in IL-6 production $(\sim 50 \%$ of $\mathbf{1})$ at $24 \mathrm{hrs}$. When TNF- $\alpha$ was measured at the same time point, only 1 produced any significant cytokine response ( $50 \%$ of $\mathbf{3}$ ) (data not shown).

Further studies with the trisaccharide showed that when $\mathbf{1}$ was cultured with mouse splenocytes, no polyclonal activation of Tor B-lymphocytes was observed (data not shown) indicating that this molecule has probably no direct effects on the murine adaptive immune system but rather, exerts its adjuvanticity exclusively via its inflammatory properties on innate immune
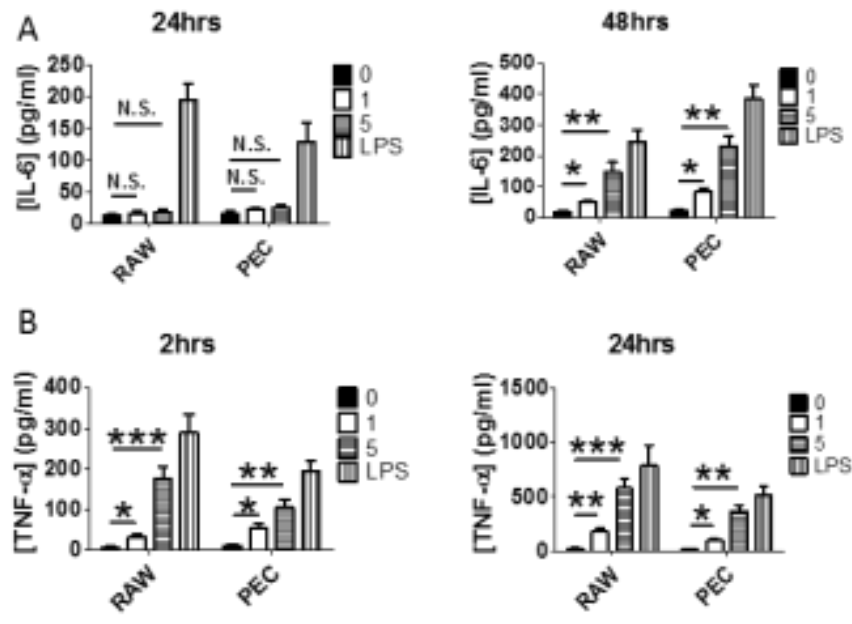

Figure 3. Synthetic oligosaccharide analog 1 stimulates IL-6 and TNF- $\alpha$ production in vitro by mouse macrophages.

The murine macrophage cell line, RAW 264.7, and mouse peritoneal macrophages (PECs) from C56BL/6 wildtype mice were cultured with 1 and $5 \mu \mathrm{g} / \mathrm{ml}$ of our synthetic oligosaccharide analog or LPS. At the time points indicated, supernatants were collected and the levels of IL-6 (A) and TNF- $\alpha$ (B) were measured by ELISA. Cytokine levels were compared to the negative control (media alone) and significance was calculated by a one-tailed student $\mathrm{t}$-test $(* \mathrm{p}<0.1, * * \mathrm{p}<0.05, * * *$ : $\mathrm{p}<0.01)$.

\subsection{Pro-inflammatory properties of the saccharide analog are TLR-4 dependent}

The adjuvant effect of many compounds is mediated via TLR signaling. ${ }^{35}$ Therefore, following our observation of the proinflammatory properties of our saccharide $\mathbf{1}$ on murine macrophages, we sought to identify whether the effect was TLRdependent. For this purpose, PECs (C57BL/6) from WT, TLR-2 deficient, and TLR-4 deficient mice were obtained and cultured at various concentrations of the saccharide molecule $\mathbf{1}$ and the pro-inflammatory cytokines IL-6, and TNF- $\alpha$, were measured as previously described (Figure 4). The adjuvant effect of the saccharide analogue $\mathbf{1}$ that was previously observed was ameliorated in the absence of TLR- 4 but was unaffected in the absence of TLR-2 suggesting that the pro-inflammatory effect observed is TLR-4 dependent (Figure 4). To verify that in order to exert its adjuvanticity, the saccharide compound needs to bind directly on TLR-4 expressed on innate immune cells, we carried out competitive binding studies between the compound and a PEconjugated anti-TLR-4 monoclonal antibody and assessed binding using flow cytometry (Figure 5). By pre-incubating mouse PECs with increasing amounts of the saccharide compound, binding of anti-TLR-4 mAb significantly decreased indicating not just specificity to this TLR but also that the saccharide and the antibody share the same binding site on the receptor. Furthermore, pre-incubation of mouse PECs with the highest concentration of the saccharide compound did not affect binding of a PE-conjugated anti-TLR-2 mAb, further confirming its specificity for TLR-4 (Figure 5).

\subsection{Discussion}

In this study, we have synthesized a new, small saccharide analog in its protected form and through various immunoassays we assessed its biological activity on innate and adaptive immunity in mouse cells. Our biological studies showed that our saccharide analog triggered the production of pro-inflammatory cytokines by murine macrophages via a TLR-4 dependent mechanism. Also, the molecule failed to activate T- and B- lymphocytes, indicating that $\mathbf{1}$ has probably no direct effects on the murine adaptive immune system but rather, exerts its adjuvanticity. exclusively via its inflammatory properties on innate immune
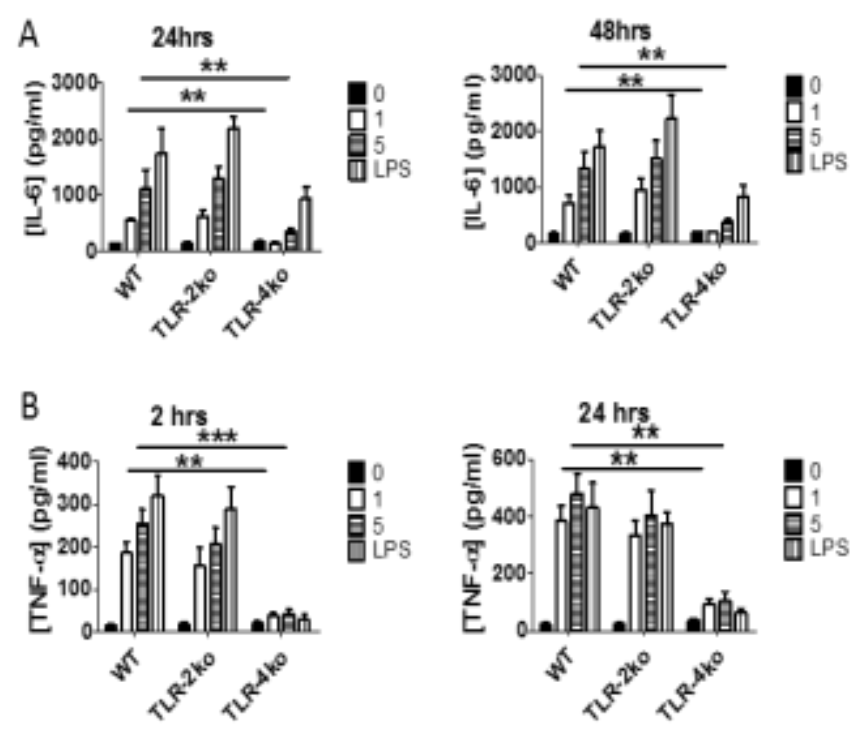
cells.

Figure 4. Pro-inflammatory properties of trisaccharide analog $\mathbf{1}$ are TLR-4-dependent.

Mouse PECs from C56BL/6 wildtype mice, TLR-2 and TLR-4 deficient mice were cultured with 1 and $5 \mu \mathrm{g} / \mathrm{ml}$ of the synthetic trisaccharide analog or LPS. At the time points indicated, supernatants were collected and the levels of IL6 (A) and TNF- $\alpha$ (B) were measured by ELISA. Cytokine levels were compared to the negative control (media alone) and significance was calculated by a one-tailed student t-test $(* *$ : $p<0.05, * * *$ : $<<0.01)$

Lipopolysaccharide (LPS), the natural ligand for TLR $-4,{ }^{36}$ is the major structural component of the outer membrane of Gramnegative bacteria. Due to its potent immunostimulatory ability, LPS acts as a potent adjuvant for vaccines by initiating a strong Th1 response. LPS activates TLR-4 signaling pathways mediated by both MyD88 and TRIF. ${ }^{37}$ Though LPS is clearly a potent adjuvant, its clinical use is also precluded due to its toxicity as well as the association of TLR-4 with a variety of diseases including: atherosclerosis, ${ }^{38}$ rheumatoid arthritis,${ }^{39}$ allergy, ${ }^{40}$ and alcohol-induced neuroinflammation. ${ }^{41^{`}}$ Thus, due to the importance of TLR-4 signaling in the regulation of inflammatory processes and its connection between innate and adaptive immunity, the evaluation of new synthetic TLR ligands, capable of agonizing or antagonizing this signaling pathway, is very important.

In our study, culturing of murine macrophages with the saccharide analog 1 had a pro-inflammatory effect based on the production of IL- 6 and TNF- $\alpha$. The absence of TLR- 4 expression by the mouse macrophages ameliorated production of the proinflammatory cytokines, indicating that the effect was TLR-4 dependent, rather than TLR-2 dependent, as it would be expected
A TLR-4 control
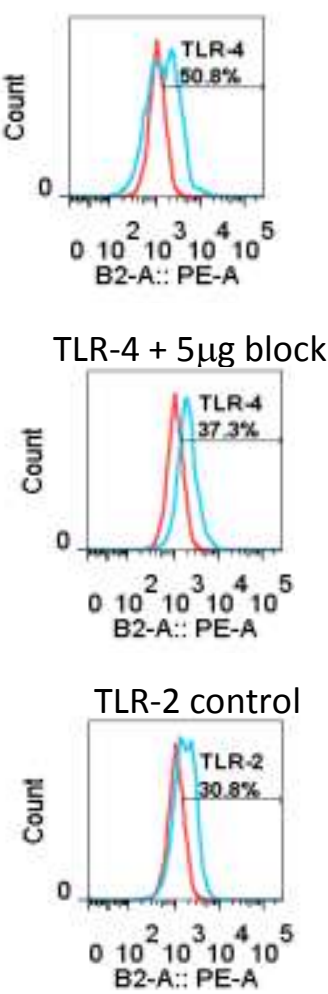

TLR-4 + 1 $\mu$ g block
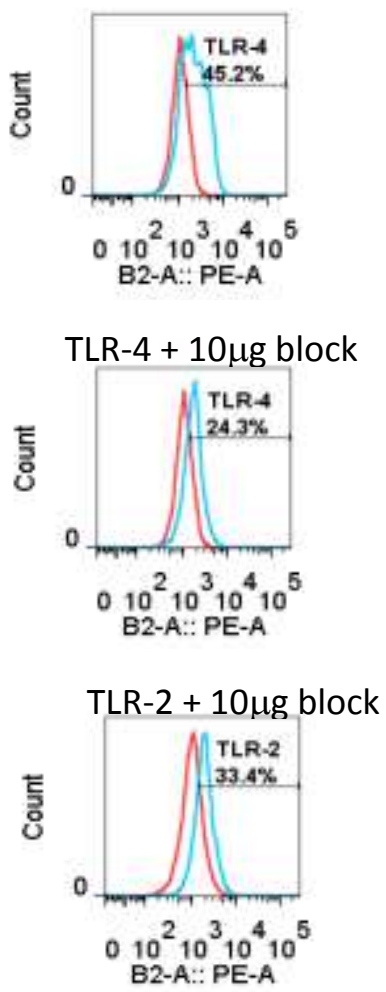

by a Lipid A derivative. Binding of our small saccharide analog to TLR-4 was confirmed by competitive assays using flow cytometry, although in the absence of additional studies it is difficult to say what the exact mechanism of binding of our molecule to TLR-4 or to the TLR-4 complex really is.

Several factors may contribute to the activity of our trisaccharide analog $\mathbf{1}$. First, the large number of lipophilic acetyl groups present in the molecule may contribute to its binding to TLR-4 and its co-receptors. The acyl groups in Lipid A have been shown to associate with $\mathrm{CD}-14,{ }^{\mathrm{x}}$ as well as, with a hydrophobic pocket in MD-2. ${ }^{\mathrm{y}}$ Their interaction with MD-2 has been shown to be essential for dimerization with TLR-4 and subsequent activation of the complex.

Figure 5. Oligosaccharide analog 1 binds on TLR-4 expressed on mouse PECs.

Mouse PECs from C56BL/6 wildtype mice were cultured for $4 \mathrm{hr}$. in the presence or absence of the synthetic oligosaccharide analog at 1,5 and 10 $\mu \mathrm{g} / \mathrm{ml}$. Cells were harvested and surface stained with either anti-TLR-4 PE or anti-TLR-2 PE mAb; (A) Blocking of antibody binding to the relevant TLRs by the oligosaccharide was assessed by flow cytometry at various concentrations of $\mathbf{1}$; (B) Levels of TLR-4 binding were graphically presented and statistically analyzed by a one-paired student t-test (N.S.: not significant, $*: \mathrm{p}<0.1, * *: \mathrm{p}<0.05)$

Also, the nature of the other protecting groups may lead to the observed immunogenicity of $\mathbf{1}$. Cytokine production with the monosaccharide precursors for $\mathbf{1}$ showed diminished levels of IL6 and TNF- $\alpha$ relative to the trisaccharide analogue. Levels were slightly higher with the galactose-based pyruvate ketal $\mathbf{3}$. The immunogenicity of the pyruvate ketal moiety has also been observed when it is present in the capsular saccharides from a range of Gram positive and Gram negative bacteria. ${ }^{23-25}$ Finally, because reduced cytokine levels were observed with the truncated sugars, it may also be possible that the combination of the residues and/or a specific chain length may be necessary for optimized TLR-4 agonism. Further structure-activity studies will be carried out to more fully address these questions.

Competition studies with $\mathbf{1}$ and mouse anti-TLR-4 mAb suggest that the saccharide directly binds with TLR-4 and more specifically at the same site at which the antibody binds. Mouse PECs were pre-treated with varying concentrations of $\mathbf{1}$, followed by the addition of PE conjugated TLR-4 mAb $(10 \mu \mathrm{g} / \mathrm{mL})$. In the absence of $\mathbf{1}$, more than $50 \%$ of the cells showed binding to PElabeled mouse anti-TLR-4 mAb. Binding decreased to 45\% when the cells were pre-treated with 1 at a concentration of 1 $\mu \mathrm{g} / \mathrm{mL}$. At $10 \mu \mathrm{g} / \mathrm{mL}$ in 1, binding to anti-TLR-4 mAb had decreased to only $24.4 \%$; more than half the binding observed in the control cells. So at equivalent concentrations of mAb and if saccharide, $\mathbf{1}$ appears to compete more effectively for binding at the same site on TLR-4. No change was observed for the binding of anti-TLR-2 mAb to the TLR-2 receptor even at the high concentration of $10 \mu \mathrm{g} / \mathrm{mL}$ of $\mathbf{1}$. This supports the data observed for PECs from TLR-2 knockout mice.

The exact nature of binding to TLR-4 is not known, nor is it known if additional co-receptors (e.g. MD-2 or CD-14) are needed to interact with $\mathbf{1}$ in order to initiate TLR-4 signaling. Additional blocking or co-blocking studies with other antibodies may help clarify these questions.

\section{Conclusions}

We believe that our study is an important step towards the discovery of new vaccine adjuvants through the chemical synthesis of a novel, low molecular weight saccharide. Using well established protocols, sugar precursors were prepared in good yields and with good anomeric selectivities. Thioalkyl glycosides were used to couple sugar fragments. A cyclohexane 
diol was used as a central "sugar surrogate". The fully-protected trisaccharide analog $\mathbf{1}$ and its precursor sugars $\mathbf{3}$ and $\mathbf{8}$ were tested in cells and their supernatents were analyzed for the production of cytokines. The component sugar fragments produced lower levels of IL- 6 and TNF- $\alpha$ than the fully assembled trisaccharide.

Using TLR-2 and TLR-4 knockout mice, the mode of signaling by the innate immune system was elucidated to be dependent on TLR-4 expression. Compound 1 did not directly activate adaptive immunity. When anti-TLR-4 mAbs were added to cells that had been pretreated with $\mathbf{1}$, competitive displacement of the saccharide was observed in a dosage-dependent fashion. This suggests that 1 and the mouse anti-TLR- 4 mAb utilize the same TLR-4 binding site, though the involvement of other coreceptors in binding and subsequent activation of the TLR are unclear from these studies.

Further cell-based experiments need to be conducted to fully elucidate the structural effects of the chain length and presence/absence of key sugar protecting groups on the agonism of TLR-4. Also, the effects of this molecule in vivo, in the context of an orally-administrable drug, need to be studied. Finally, downstream signaling of the activated TLR needs to be examined for dependency on MyD88 and TRIF/TRAM effector proteins.

\section{Experimental Section}

\subsection{Chemistry}

\subsubsection{General methods.}

Proton nuclear magnetic resonance $\left({ }^{1} \mathrm{H}\right.$ NMR) spectra were recorded on a Varian Inova $(500 \mathrm{MHz})$ spectrometer. NMR samples were dissolved in $\mathrm{d}_{6}$-acetone, $\mathrm{d}_{1^{-}}$-chloroform or $\mathrm{d}_{6^{-}}$ DMSO and chemical shifts were reported in ppm relative to the residual non-deuterated solvent or to the methyl protons on tetramethylsilane (TMS, $0.00 \mathrm{ppm}$ ). ${ }^{1} \mathrm{H}$ NMR data are reported as follows: chemical shift, integration, multiplicity ( $\mathrm{s}=$ singlet; $\mathrm{d}=$ doublet; $\mathrm{dd}=$ doublet of doublet; ddd $=$ doublet of doublet of doublets; $\mathrm{m}=$ multiplet), coupling constant, and assignment. ${ }^{13} \mathrm{C}$ NMR were recorded on the same instrument $(125 \mathrm{MHz})$. The ${ }^{13} \mathrm{C}$ chemical shift were reported relative to the references at 29.84, 77.23 and $39.51 \mathrm{ppm}$, respectively. All the NMR experiments were run at room temperature $\left(25^{\circ} \mathrm{C}\right)$ and assignments were done by using gCOSY and gHMQC. The mass spectra were obtained at the University of Illinois (Champaign-Urbana). Both the higher resolution and the low resolution mass spectra were obtained by ESI (electron spray ionization).

Melting points $(\mathrm{mp})$ were measured on a Mel-Temp melting point apparatus (Laboratory Devices, Inc., USA).The optical rotations were recorded on automatic polarimeter (Rudolph Instruments, New Jersey USA). Reactions were monitored by thin-layer chromatography (TLC) on $0.25 \mathrm{~mm}$ silica gel coated aluminum sheets 60 F254 (Analtech). Silica gel (particle size 40$63 \AA$, 230-400 mesh) (Silicycle) was used for flash column chromatography. Preparative, thin-layer, chromatographic separations were carried out on $2000 \mu \mathrm{m}$ silica gel 60 coated glass plates.

All the reactions were carried out in oven-dried glassware under nitrogen. Sugar precursors were purchased either from Aldrich Chemical Co. or from Carbosynth. Other reagents were purchased from either Aldrich Chemical Company or Alfa Aesar and were used as supplied.

\subsection{Synthesis of Fragment 2}

4.2.1 Thioethyl-2-phthalimido-3,4,6-tri- $O$-acetyl- $\beta$-Dglucopyranose (2): Starting from commercially-available glucosamine hydrochloride, compound $\mathbf{2}$ was prepared in four steps using known literature procedures. ${ }^{26-28}$ First, neutralization of the hydrochloride salt, then installation of the phthalamido protecting group on nitrogen, followed by peracetylation of the hydroxyl groups gave $\mathbf{8}$. Then, treatment with ethanethiol and boron trifluoride etherate gave the thioethyl glycosyl donor (79 $\%)$ 2. Yields, melting points and compound spectroscopic data for each product were in good agreement with prior literature reports. ${ }^{26-28}$

\subsection{Synthesis of Fragment 3}

4.3.1. Known Precursors: Compounds 10, 11, 12 and 13 were synthesized sequiv.uentially, starting with $1,2,3,4,6$ - pentaO-acetyl- $\beta$-D-galactopyranose 9 using procedures described in the literature. Their yields and spectroscopic properties were in good agreement with the literature. ${ }^{26,27,29,30}$

\subsubsection{Thiophenyl-2- $O$-acetyl-3-O-benzoyl-4,6-O- benzylidene- $\beta$-D-galactopyranose (14): ${ }^{31}$}

To a solution of thiophenyl-3- $O$-benzoyl-4,6- $O$-benzylidene$\beta$-D-galactopyranose $13(2.0 \mathrm{~g}, 4.31 \mathrm{mmol})$ in $10 \mathrm{~mL}$ of $N, N, N$ triethylamine was added $N, N$-dimethylaminopyridine $(39 \mathrm{mg}$, 0.08 equiv.) and the mixture was stirred at $0{ }^{\circ} \mathrm{C}$ for $30 \mathrm{~min}$. To the ice-cold solution was added $508 \mathrm{mg}$ (1.5 equiv.) of acetyl chloride dropwise and the reaction was vigorously stirred at $0{ }^{\circ} \mathrm{C}$ initially, then at r.t. for 2 days. The reaction was terminated by diluting with $\mathrm{CH}_{2} \mathrm{Cl}_{2}(50 \mathrm{~mL})$ and, by washing with $2 \mathrm{~N} \mathrm{HCl}(2$ x $25 \mathrm{~mL}$ ) and saturated $\mathrm{NaHCO}_{3}$ solution $(2 \times 25 \mathrm{~mL})$. The organic layer was dried over anhydrous $\mathrm{MgSO}_{4}$ and evaporate in vacuo to give $2.44 \mathrm{~g}$ of the crude product as an orange fluffy solid. Purification was carried out by flash column chromatography using 30\% EtOAc in hexanes as the eluent. $1.3 \mathrm{~g}$ $(60 \%)$ of the desired product was obtained as a yellow oily liquid. $\mathrm{R}_{\mathrm{f}}$ (30\% EtOAc/hexanes): 0.44 .

${ }^{1} \mathrm{H}$ NMR $\left(500 \mathrm{MHz}, \mathrm{CDCl}_{3}\right) \delta$ 7.99-7.97 (m, 2H, Ar), 7.63-7.64 (m, 2H, Ar), 7.52-7.55 (m, 1H, Ar), 7.31-7.41 (m, 8H, Ar), 5.56 (d, $\left.1 \mathrm{H}, \mathrm{J}_{2,3}=9.9 \mathrm{~Hz}, \mathrm{H}-2\right), 5.48(\mathrm{~s}, 1 \mathrm{H}, \mathrm{Bn}-\mathrm{Ar}), 5.20$ (dd, 1H, $\mathrm{J}_{2,1}$ $\left.=9.9 \mathrm{~Hz}, \mathrm{~J}_{2,3}=9.8 \mathrm{~Hz}, \mathrm{H}-3\right), 4.79\left(\mathrm{~d}, 1 \mathrm{H}, \mathrm{J}_{1,2}=9.8 \mathrm{~Hz}, \mathrm{H}-1\right), 4.54$ $(\mathrm{s}, 1 \mathrm{H}, \mathrm{H}-4), 4.42\left(\mathrm{~d}, 1 \mathrm{H}, \mathrm{J}_{6,6},=12.4 \mathrm{~Hz}, \mathrm{H}-6\right), 4.06\left(\mathrm{~d}, 1 \mathrm{H}, \mathrm{J}_{6},{ }_{6}=\right.$ $12.4 \mathrm{~Hz}, \mathrm{H}-6$ '), 3.69 (s, 1H, H-5), 2.01 (s, 3H, -CO-CH ${ }_{3}$; ${ }^{13} \mathrm{C}$ NMR (125 MHz, $\left.\mathrm{CDCl}_{3}\right) \delta 170.1\left(\mathrm{~g}-\mathrm{CO}-\mathrm{CH}_{3}\right), 165.9$ (-CO-Ar), 137.3, 133.9, 133.0, 130.0, 129.3, 128.6, 127.8, $125(\mathrm{CH}, \mathrm{Ar})$, 108.9 (Bn-Ar), 89.8 (C-1), 79.6 (C-4), 78.9 (C-5), 73.8 (C-3), 70.4 (C-2), 67.8 (C-6), $21.0\left(\mathrm{CH}_{3}\right)$; LRMS (ESI): 524.2 $\left(\mathrm{M}+\mathrm{NH}_{4}\right)^{+}:$.

4.3.3. Thiophenyl-2- $O$-acetyl-3- $O$-benzoyl-4,6- $O$-pyruvate$\beta$-D-galactopyranose (3): ${ }^{32}$

To a solution of thiophenyl-2- $O$-acetyl-3- $O$-benzoyl-4,6- $O$ benzylidene- $\beta$-D-galactopyranose $\mathbf{1 4}$ in anhydrous dichloromethane $(20 \mathrm{~mL})$ at $-15{ }^{0} \mathrm{C}$ was added dropwise a mixture of $20 \% \mathrm{v} / \mathrm{v}$ trifluoroacetic acid ( $880 \mathrm{mg}, 6$ equiv.uiv.) in $\mathrm{CH}_{2} \mathrm{Cl}_{2}$. The mixture was brought to r.t. and stirred overnight in an atmosphere of $\mathrm{N}_{2}$. The reaction was terminated by the addition of excess $\mathrm{CH}_{2} \mathrm{Cl}_{2}(30 \mathrm{~mL})$, and washed with saturated $\mathrm{NaHCO}_{3}$ solution $(2 \times 25 \mathrm{~mL})$ and water $(2 \times 25 \mathrm{~mL})$. The organic layer was separated and dried over anhydrous $\mathrm{Na}_{2} \mathrm{SO}_{4}$, and evaporated in vacuo to yield $820 \mathrm{mg}$ of the crude 4,6-diol sugar. To a suspension of the intermediate $(10 \mathrm{mg}, 0.024 \mathrm{mmol})$ in methyl pyruvate (58 mg, 23.5 equiv.uiv.) was added $\mathrm{BF}_{3}$-etherate dropwise. The mixture was allowed to stir at r.t. overnight in an atmosphere of $\mathrm{N}_{2}$. The reaction was terminated by the addition of $1 \mathrm{~mL}$ of triethylamine to neutralize the acid. The mixture was 
poured into $25 \mathrm{~mL}$ of saturated $\mathrm{NaHCO}_{3}$ solution and was extracted with $\mathrm{CH}_{2} \mathrm{Cl}_{2}(2 \times 50 \mathrm{~mL})$. The organic layer was dried over anhydrous $\mathrm{Na}_{2} \mathrm{SO}_{4}$ and concentrated in vacuo to give the desired pyruvate adduct in its crude form. The crude product was purified by preparatory TLC using 50\% EtOAc in hexanes mixture as the eluent (with trace amounts of triethylamine) to give $10 \mathrm{mg}(80 \%)$ of the pyruvate adduct. $\mathrm{R}_{\mathrm{f}} \quad(50 \%$ EtOAc/hexanes): $0.77 ;{ }^{1} \mathrm{H}$ NMR $\left(500 \mathrm{MHz}, \mathrm{CDCl}_{3}\right) \delta$ 7.97-8.01 (m, 3H, Ar), 7.92-7.95 (m, 2H, Ar), 7.5-7.54 (m, 2H, Ar), 7.44$7.49(\mathrm{~m}, 3 \mathrm{H}, \mathrm{Ar}), 5.45-5.47(\mathrm{~m}, 1 \mathrm{H}, \mathrm{H}-2), 5.29-5.34(\mathrm{~m}, 1 \mathrm{H}, \mathrm{H}-$ 3), $5.08\left(\mathrm{dd}, 1 \mathrm{H}, \mathrm{J}_{1,2}=10 \mathrm{~Hz}, \mathrm{~J}_{1,3}=2.8 \mathrm{~Hz}, \mathrm{H}-1\right), 4.63(\mathrm{dd}, 1 \mathrm{H}$, $\left.\mathrm{J}_{4,3}=7.8 \mathrm{~Hz}, \mathrm{~J}_{4,5}=3.4, \mathrm{H}-4\right), 4.09-4.1(\mathrm{~m}, 1 \mathrm{H}, \mathrm{H}-6), 4.06-4.07$ (m, 1H, H-6'), 3.89-3.9 (m, 1H, H-5), 3.27 (s, 3H, - $\mathrm{OCH}_{3}$ ), 2.01 $\left(\mathrm{s}, 3 \mathrm{H},-\mathrm{CO}-\mathrm{CH}_{3}\right), 1.63\left(\mathrm{~s}, 3 \mathrm{H}, \mathrm{CH}_{3}\right) ;{ }^{13} \mathrm{C} \mathrm{NMR}(125 \mathrm{MHz}$, $\left.\mathrm{CDCl}_{3}\right) \delta 170.2\left(-\mathrm{CO}-\mathrm{CH}_{3}\right), 168.9\left(-\mathrm{CO}-\mathrm{OCH}_{3}\right), 165.9$ (-CO-Ar) 133.9, 133, 130.1, 129.3, 128.6, 125.1 (Ar), 114.9 (Pyr), 89.8 (C1), 79.1 (C-4), 78.9 (C-5), 73.8 (C-3), 70.4 (C-2), 65.1 (C-6), $52.5\left(-\mathrm{CO}-\mathrm{OCH}_{3}\right), 25.5\left(\mathrm{CH}_{3}\right), 21.0 \mathrm{~b}\left(-\mathrm{CO}-\mathrm{CH}_{3}\right)$; HRMS (ESI): Calcd $\mathrm{C}_{25} \mathrm{H}_{26} \mathrm{O}_{9} \mathrm{NaS}$ for $(\mathrm{M}+\mathrm{Na})^{+}:$: 525.1195. Found: 525.1205 .

\subsection{Synthesis of Central Cyclohexane Core}

\subsubsection{4-O-tert-butyldimethylsilylcyclohexanol (4): ${ }^{33}$}

To a solution of cis/trans mixture of 1, 4-cyclohexanediol $\mathbf{1 5}$ (200 mg, $1.72 \mathrm{mmol}$ ) in $N, N$-dimethylformamide $(5 \mathrm{~mL})$ was added 2.5 equiv.uiv. of imidazole $(293 \mathrm{mg}$ ) and the mixture was stirred at r.t. for $30 \mathrm{~min}$. To the solution was added tertbutyldimethylsilyl chloride (1.25 equiv.uiv., $293 \mathrm{mg}$ ) and the mixture was further stirred for 3 days in an atmosphere of $\mathrm{N}_{2}$. At the end of the third day, the mixture was diluted with excess $\mathrm{CH}_{2} \mathrm{Cl}_{2}(30 \mathrm{~mL})$, washed with water $(5 \times 25 \mathrm{~mL})$ and saturated $\mathrm{NaCl}$ (aq) solution $(1 \times 25 \mathrm{~mL})$. The organic layer was dried over anhydrous $\mathrm{Na}_{2} \mathrm{SO}_{4}$ and then evaporated in vacuo to give $276 \mathrm{mg}$ of the crude product. Purification was done by flash column chromatography using 50\% EtOAc in hexanes as the eluent which gave $196 \mathrm{mg}(50 \%)$ of the product $4 . \mathrm{R}_{\mathrm{f}}(50 \%$ EtOAc/hexanes): 0.87 .

${ }^{1} \mathrm{H}$ NMR $\left(500 \mathrm{MHz}, \mathrm{CDCl}_{3}\right) \delta 3.79-3.83(\mathrm{~m}, 1 \mathrm{H}, \mathrm{H}-1), 3.65-3.70$ $(\mathrm{m}, 1 \mathrm{H}, \mathrm{H}-4), 1.6-1.77\left(\mathrm{~m}, 6 \mathrm{H}, \mathrm{H}-2^{\mathrm{a}}, 2^{\mathrm{e}}, 3^{\mathrm{e}}, 5^{\mathrm{e}}, 6^{\mathrm{a}}, 6^{\mathrm{e}}\right), 1.46-1.5$ $\left(\mathrm{m}, 1 \mathrm{H}, \mathrm{H}-3^{\mathrm{a}}\right), 1.28-1.32\left(\mathrm{~m}, 1 \mathrm{H}, \mathrm{H}-5^{\mathrm{a}}\right), 0.89$ (s, $9 \mathrm{H}, t$-butyl $), 0.04$ $\left(\mathrm{s}, 6 \mathrm{H}, \mathrm{CH}_{3}\right) ;{ }^{13} \mathrm{C} \mathrm{NMR}\left(125 \mathrm{MHz}, \mathrm{CDCl}_{3}\right) \delta 78.1$ (C-4), $69.7(\mathrm{C}-$ 1), 32.1 (C-2, 6), 1.3 (C-3, 5), 30.9 (- $\mathrm{CCH}_{3}, t$-butyl), 25.9 ($\mathrm{CCH}_{3}, t$-butyl), $-2.0\left(\mathrm{CH}_{3}\right)$.

\subsection{Formation of Trisaccharide Analog}

4.5.1.4-tert-butyldimethylsilyl-cyclohexyl)-2-phthalimido3,4,6-tri- $O$-acetyl- $\beta$-D-glucopyranose $(16):^{26}$

Into a clean oven dried $25 \mathrm{~mL}$ rb flask was taken $575 \mathrm{mg}(1.2$ $\mathrm{mmol}$ ) of thioethyl-2-phthalimido-3,4,6-tri- $O$-acetyl- $\beta$-Dglucopyranose 2. To it was added $15 \mathrm{~mL}$ anhydrous $\mathrm{CH}_{2} \mathrm{Cl}_{2}$ and the mixture was cooled to $-78{ }^{0} \mathrm{C}$ upon stirring in an inert atmosphere. To the mixture was added $N$-iodosuccinimide $(2.5$ equiv., $675 \mathrm{mg}$ ) and it was stirred at $-78{ }^{\circ} \mathrm{C}$ for an additional 30 min. Keeping the temperature constant, $10 \mu \mathrm{L}$ ( 0.05 equiv.) of trimethylsilyl trifluoromethanesulfonate (TMSOTf) was added dropwise to the mixture upon vigorous stirring. To the mixture was added dropwise a solution of 4-O-tert-butyldimethylsilylcyclohexanol 4 (1.2 equiv., $331 \mathrm{mg}$ ) in $\mathrm{CH}_{2} \mathrm{Cl}_{2}(2 \mathrm{~mL})$ and the reaction was stirred at $-78{ }^{0} \mathrm{C}$ for $90 \mathrm{~min}$. The reaction was terminated and the mixture was diluted with excess $\mathrm{CH}_{2} \mathrm{Cl}_{2}(100$ $\mathrm{mL})$ and washed with saturated $\mathrm{NaHCO}_{3}$ solution $(1 \times 50 \mathrm{~mL})$. The organic layer was dried over anhydrous $\mathrm{MgSO}_{4}$, filtered and concentrated to dryness in vacuo to yield $1.0 \mathrm{~g}$ of the crude product as a dark brown oily syrup. Purification was done by flash column chromatography using gradient elution $(30 \%, 40 \%$,
$50 \%, 60 \%, 70 \%, 80 \%, 90 \%$ EtOAc in hexanes) which yielded $503 \mathrm{mg}(65 \%)$ of the product gas a pale, yellow, oily syrup. $\mathrm{R}_{\mathrm{f}}$ (60\% EtOAc/hexanes): 0.83 .

${ }^{1} \mathrm{H}$ NMR $\left(500 \mathrm{MHz}, \mathrm{CDCl}_{3}\right) \delta$ 7.84-7.87 (m, 2H, Ar), 7.71-7.75 (m, 2H, Ar), 5.76-5.83 (m, 1H, H-3), $5.44\left(\mathrm{dd}, 1 \mathrm{H}, \mathrm{J}_{1,2}=8.75 \mathrm{~Hz}\right.$, $\left.\mathrm{J}_{1,3}=2.4 \mathrm{~Hz}, \mathrm{H}-1\right), 5.13-5.18(\mathrm{~m}, 1 \mathrm{H}, \mathrm{H}-4), 4.28-4.35(\mathrm{~m}, 2 \mathrm{H}, \mathrm{H}-$ $2,6), 4.16\left(\mathrm{~d}, 1 \mathrm{H}, \mathrm{J}_{6,6}=12.2 \mathrm{~Hz}, \mathrm{H}-6\right.$ ') 3.84-3.87 (m, 1H, H-5), 3.59-3.68 (m, 1H, Cyclohexyl-H-1), 3.49-3.53 (m, $1 \mathrm{H}$, Cyclohexyl-H-4), 2.11 (s, 3H, -CO- $\mathrm{CH}_{3}$ ), 2.03 (s, 3H, -CO- $\mathrm{CH}_{3}$ ), $1.86\left(\mathrm{~s}, 3 \mathrm{H},-\mathrm{CO}-\mathrm{CH}_{3}\right), 1.68-1.8\left(\mathrm{~m}, 2 \mathrm{H}\right.$, Cyclohexyl-H-2 $\left.{ }^{\mathrm{e}}, 6^{\mathrm{e}}\right)$, 1.24-1.40 (m, 4H, Cyclohexyl-H-3 $\left.3^{\mathrm{e}}, 2^{\mathrm{a}}, 5^{\mathrm{e}}, 6^{\mathrm{a}}\right), 1.19-1.40(\mathrm{~m}, 1 \mathrm{H}$, Cyclohexyl-H-3 ${ }^{\mathrm{a}}$ ), 0.83 (s, 5H, H- $t$-butyl), 0.74 (s, 4H, H- $t$ butyl), -0.04 (s, 3H, $\left.\mathrm{CH}_{3}\right),-0.08\left(\mathrm{~s}, 3 \mathrm{H}, \mathrm{CH}_{3}\right),-0.12\left(\mathrm{~s}, 3 \mathrm{H}, \mathrm{CH}_{3}\right)$; ${ }^{13} \mathrm{C}$ NMR $\left(125 \mathrm{MHz}, \mathrm{CDCl}_{3}\right) \delta 172.96,171.06\left(-\mathrm{CO}-\mathrm{CH}_{3}\right)$, 169.84 (-CO-N-), 134.57, 123.92 (Ar), 97.05 (C-1), 72.11 (C-5), 71.21 (C-3), 69.59 (C-4), 62.60 (C-6), 49.66 (C-2), 31.13 ($\mathrm{CCH}_{3}, t$-butyl), 26.15, 26.02 (-CCH $3, t$-butyl), 21.13, 21.0, 20.82 $\left(-\mathrm{CO}-\mathrm{CH}_{3}\right),-4.43\left(\mathrm{CH}_{3}\right)$; LRMS (ESI): $(\mathrm{M}+\mathrm{H})^{+}$: 648.3 .

\subsubsection{Cyclohexyl-2-phthalimido-3,4,6-tri- $O$-acetyl- $\beta$-D- glucopyranose (17): ${ }^{26}$}

Into a clean oven dried $10 \mathrm{~mL}$ rb flask was taken $25 \mathrm{mg}$ $(0.052 \mathrm{mmol})$ of thioethyl-2-phthalimido-3,4,6-tri- $O$-acetyl- $\beta$-Dglucopyranose, 2. To it was added $5 \mathrm{~mL}$ anhydrous $\mathrm{CH}_{2} \mathrm{Cl}_{2}$ and the mixture was cooled to $-78{ }^{0} \mathrm{C}$ upon stirring in an inert atmosphere. To the mixture was added $N$-iodosuccinimide $(2.5$ equiv., $30 \mathrm{mg}$ ) and it was stirred at $-78{ }^{\circ} \mathrm{C}$ for $30 \mathrm{~min}$. Keeping the temperature constant, $0.46 \mu \mathrm{L}$ ( 0.05 equiv.) of trimethylsilyl trifluoromethanesulfonate (TMSOTf) was added dropwise to the mixture upon vigorous stirring. To the resulting mixture was added dropwise a solution of 4-O-tert-butyldimethylsilyl cyclohexanol 4 (1.2 equiv., $14.35 \mathrm{mg}$ ) in $\mathrm{CH}_{2} \mathrm{Cl}_{2}(1 \mathrm{~mL})$ and the reaction was stirred at $-78{ }^{0} \mathrm{C}$ for $7 \mathrm{~h}$. The reaction was terminated and the mixture was diluted with $\mathrm{CH}_{2} \mathrm{Cl}_{2}(25 \mathrm{~mL})$ and washed with saturated $\mathrm{NaHCO}_{3}$ solution $(1 \mathrm{x} 25 \mathrm{~mL})$. The organic layer was dried over anhydrous $\mathrm{MgSO}_{4}$, filtered and concentrated to dryness in vacuo to yield the crude product as an orange-brown, oily syrup. Purification was done by preparatory TLC using $80 \%$ EtOAc in hexanes as the solvent which yielded $32 \mathrm{mg}(95 \%)$ of the product $\mathbf{1 7}$ as a yellowish oily syrup. $\mathrm{R}_{\mathrm{f}}$ (60\% EtOAc/hexanes): 0.157.

${ }^{1} \mathrm{H}$ NMR $\left(500 \mathrm{MHz}, \mathrm{CDCl}_{3}\right) \delta$ 7.84-7.86 (m, 2H, Ar), 7.72-7.76 (m, 2H, Ar), 5.75-5.82 (m, 1H, H-3), $5.44\left(\mathrm{dd}, 1 \mathrm{H}, \mathrm{J}_{1,2}=8.4 \mathrm{~Hz}\right.$, $\left.\mathrm{J}_{1,3}=6.4 \mathrm{~Hz}, \mathrm{H}-1\right), \quad 5.15-5.19(\mathrm{~m}, 1 \mathrm{H}, \mathrm{H}-4), 4.28-4.36$ (overlapping m, 2H, H-2, H-6), $4.16\left(\mathrm{~m}, 1 \mathrm{H}, \mathrm{J}_{6,6}=10.8 \mathrm{~Hz}, \mathrm{H}-\right.$ 6'), 3.85-3.88 (m, 1H, H-5), 3.73-3.77 (m, 1H, Cyclohexyl-H-1), 3.56-3.65 (m, 1H, Cyclohexyl-H-4), $2.11\left(\mathrm{~s}, 3 \mathrm{H},-\mathrm{CO}-\mathrm{CH}_{3}\right), 2.03$ (s, 3H, -CO- $\left.\mathrm{CH}_{3}\right), 1.95-1.98\left(\mathrm{~m}, 1 \mathrm{H}\right.$, Cyclohexyl-H-2 $\left.{ }^{\mathrm{e}}\right), 1.86(\mathrm{~s}$, $\left.3 \mathrm{H},-\mathrm{CO}-\mathrm{CH}_{3}\right), 1.69-1.76\left(\mathrm{~m}, 1 \mathrm{H}\right.$, Cyclohexyl-H-6 $\left.{ }^{\mathrm{e}}\right), 1.33-1.43$ (m, 2H, Cyclohexyl-H-3 $\left.3^{\mathrm{e}}, 5^{\mathrm{e}}\right), 1.17-1.31(\mathrm{~m}, 2 \mathrm{H}$, Cyclohexyl-H$\left.3^{\mathrm{a}}, 5^{\mathrm{a}}\right) ;{ }^{13} \mathrm{C}$ NMR $\left(125 \mathrm{MHz}, \mathrm{CDCl}_{3}\right) \delta 170.73,170.22$ (-CO$\mathrm{CH}_{3}$ ), 169.51, 165.52 (-CO-N-), 134.35, 131.38, 123.6 (Ar), 96.85 (C-1), 76.86 (Cyclohexyl-C-1), 71.78 (C-3, 5), 70.88 (C4), 69.19 (Cyclohexyl-C-4), 62.23 (C-6), 54.86 (C-2), 30.47, 30.06 (Cyclohexyl-C-2, 3, 5, 6), 20.78, 20.65, $20.46\left(-\mathrm{CO}-\mathrm{CH}_{3}\right)$. LRMS (ESI): $534.2(\mathrm{M}+\mathrm{H})^{+}$.

4.5.3. (Cyclohexyl-2-phthalimido-3,4,6-tri- $O$-acetyl- $\beta$-Dglucopyranosyl)-2- $O$-acetyl-3- $O$-benzoyl-4,6- $O$-pyruvate- $\beta$-Dgalactopyranose (1):

Thiophenyl-2- $O$-acetyl-3- $O$-benzoyl-4,6- $O$-pyruvate- $\beta$-Dgalactopyranose 2 (62 $\mathrm{mg}, 1.3$ equiv.) and $5 \mathrm{~mL}$ of anhydrous $\mathrm{CH}_{2} \mathrm{Cl}_{2}$ were taken in a clean oven tried $10 \mathrm{~mL}$ flask and the mixture was stirred at $-42{ }^{0} \mathrm{C}\left(\mathrm{CH}_{3} \mathrm{CN} /\right.$ dry ice $)$ in an inert atmosphere for $15 \mathrm{~min}$. $\mathrm{N}$-iodosuccinimide (69 $\mathrm{mg}, 2.5$ equiv.) 
was added to the mixture and it was stirred for an additional 30 min at $-42{ }^{0} \mathrm{C}^{26}$ Keeping the temperature constant, $1.3 \mu \mathrm{L}$ of TMSOTf ( 0.05 equiv.) was added to the mixture dropwise with vigorous stirring. To the mixture was added a solution of cyclohexyl-2-phthalimido-3,4,6-tri- $O$-acetyl- $\beta$-D-glucopyranose $17(50 \mathrm{mg}, 0.094 \mathrm{mmol})$ in anhydrous $\mathrm{CH}_{2} \mathrm{Cl}_{2}(1 \mathrm{~mL})$ and the reaction was run at $-42{ }^{0} \mathrm{C}$ for $3 \mathrm{~h}$ with continuous stirring. The reaction was terminated by adding excess $\mathrm{CH}_{2} \mathrm{Cl}_{2}(40 \mathrm{~mL})$, it was washed with saturated $\mathrm{NaHCO}_{3}$ solution $(1 \times 50 \mathrm{~mL})$ and $10 \%$ w/v $\mathrm{Na}_{2} \mathrm{~S}_{2} \mathrm{O}_{3}$ solution $(1 \mathrm{x} 50 \mathrm{~mL})$. The organic layer was separated, dried over anhydrous $\mathrm{MgSO}_{4}$, filtered and concentrated to dryness in vacuo to yield $135 \mathrm{mg}$ of the crude product as an orange oily syrup. Purification was done by preparatory TLC technique using $60 \%$ EtOAc in hexanes as the solvent, to afford $50 \mathrm{mg}(57.6 \%)$ of the product 1 as an off-white solid.

${ }^{1} \mathrm{H}$ NMR $\left(500 \mathrm{MHz}, \mathrm{CDCl}_{3}\right) \delta$ 7.99-8.04 (m, 2H, Ar), 7.91-7.96 (m, 1H, Ar), 7.83-7.88 (m, 1H, Ar), 7.73-7.77 (m, 1H, Ar), 7.49$7.54(\mathrm{~m}, 1 \mathrm{H}, \mathrm{Ar}), 7.36-7.41(\mathrm{~m}, 1 \mathrm{H}, \mathrm{Ar}), 7.35-7.41$ (m, 2H, Ar), 5.73-5.80 (m, 1H, Hglu-1), 5.62-5.66 (m, 1H, $\left.\mathrm{H}_{\mathrm{ga}} \mathrm{l}-1\right)$, 5.36-5.46 (m, 2H, $\left.\mathrm{H}_{\mathrm{glu}}-3, \mathrm{H}_{\mathrm{gal}}-2\right), 5.13-5.19\left(\mathrm{~m}, 1 \mathrm{H}, \mathrm{H}_{\mathrm{gal}}-3\right)$, 4.48-4.60 (m, $\left.1 \mathrm{H}, \mathrm{H}_{\mathrm{glu}}-4\right), 4.26-4.34\left(\mathrm{~m}, 2 \mathrm{H}, \mathrm{H}_{\mathrm{gal}^{-}}-4, \mathrm{H}_{\mathrm{glu}}-2\right)$, 4.10-4.27 (m, $2 \mathrm{H}$, $\left.\mathrm{H}_{\mathrm{glu}}-5,6\right), 3.93-4.08\left(\mathrm{~m}, 2 \mathrm{H}, \mathrm{H}_{\mathrm{glu}}-6\right.$ ', $\left.\mathrm{H}_{\mathrm{gal}}-6\right), 3.80-3.90(\mathrm{~m}, 2 \mathrm{H}$, $\mathrm{H}_{\mathrm{gal}}{ }^{-6}$ ', Cyclohexyl-H-1), 3.73-3.78 (m, 1H, $\left.\mathrm{H}_{\mathrm{gal}}-5\right)$ ), 3.61-3.7 (m, $\left.3 \mathrm{H},-5 \mathrm{OCH}_{3}\right), 3.41-3.53(\mathrm{~m}, 1 \mathrm{H}$, Cyclohexyl-H-4), $2.11(\mathrm{~s}, 1 \mathrm{H},-$ $\left.\mathrm{CO}-\mathrm{CH}_{3}\right), 2.10\left(\mathrm{~s}, 1 \mathrm{H},-\mathrm{CO}-\mathrm{CH}_{3}\right), 2.06\left(\mathrm{~s}, 1 \mathrm{H},-\mathrm{CO}-\mathrm{CH}_{3}\right), 1.87$ (s, $\left.1 \mathrm{H},-\mathrm{CO}-\mathrm{CH}_{3}\right), 1.86\left(\mathrm{~s}, 1 \mathrm{H},-\mathrm{CO}-\mathrm{CH}_{3}\right), 1.85\left(\mathrm{~s}, 1 \mathrm{H},-\mathrm{CO}-\mathrm{CH}_{3}\right)$, 1.65-1.83 (m, 4H, Cyclohexyl-H-2 $\left.2^{\mathrm{a}}, 2^{\mathrm{e}}, 6^{\mathrm{a}}, 6^{\mathrm{e}}\right), 1.57(\mathrm{~s}, 3 \mathrm{H},-\mathrm{CO}-$ $\left.\mathrm{CH}_{3}\right), 1.37-1.42\left(\mathrm{~m}, 1 \mathrm{H}\right.$, Cyclohexyl-H-3 $\left.{ }^{\mathrm{e}}\right), 1.27-1.31(\mathrm{~m}, 1 \mathrm{H}$, Cyclohexyl-H-5 $\left.5^{\mathrm{e}}\right) \quad 1.25 \quad\left(\mathrm{~s}, \quad 3 \mathrm{H}, \mathrm{CH}_{3}\right), 0.86-0.92 \quad(\mathrm{~m}, \quad 1 \mathrm{H}$, Cyclohexyl-H-3 3 ) ${ }^{13} \mathrm{C}$ NMR $\left(125 \mathrm{MHz}, \mathrm{CDCl}_{3}\right) \delta 170.70,170.20$ $\left(-\mathrm{CO}-\mathrm{CH}_{3}\right), 169.49\left(-\mathrm{CO}-\mathrm{OCH}_{3}\right), 165.89$ (-CO-N-), 134.37, 133.16, 131.31, 129.88, 129.77, 129.67, 128.42, 128.36, 127.47, 123.61 (Ar), 100.36 (pyr), $98.69\left(\mathrm{C}_{\mathrm{gal}}-1\right), 96.65\left(\mathrm{C}_{\mathrm{glu}}-1\right), 96.12$ (Cyclohexyl-C-1), 95.91 (Cyclohexyl-C-4), $72.04\left(\mathrm{C}_{\mathrm{gal}}-4\right), 71.93$ $\left(\mathrm{C}_{\mathrm{gal}}{ }^{-5}\right), 71.79\left(\mathrm{C}_{\mathrm{glu}^{-}}-5\right), 70.82\left(\mathrm{C}_{\mathrm{gal}^{-}}-3\right), 69.22\left(\mathrm{C}_{\mathrm{glu}^{-}}-3\right), 69.13\left(\mathrm{C}_{\mathrm{gal}^{-}}\right.$ 4), $66.7\left(\mathrm{C}_{\mathrm{gal}}-2\right), 65.34\left(\mathrm{C}_{\mathrm{gal}}-6\right), 64.01\left(\mathrm{C}_{\mathrm{glu}}-6\right), 62.17\left(\mathrm{C}_{\mathrm{glu}}-2\right)$, $54.8\left(\mathrm{CO}-\mathrm{OCH}_{3}\right), 31.93,29.70,29.36,28.98$ (Cyclohexyl-C-2, 3, 5, 6), $25.72\left(\mathrm{CH}_{3}\right), 20.78,20.65,20.47\left(-\mathrm{CO}-\mathrm{CH}_{3}\right)$; HRMS (ESI): Calcd $\mathrm{C}_{45} \mathrm{H}_{51} \mathrm{NO}_{20} \mathrm{Na}$ for $(\mathrm{M}+\mathrm{Na})^{+}$: 948.2902. Found: 948.2899.

\subsection{Biological Evaluation}

\subsubsection{Mice}

C57BL/6, TLR-2, and TLR-4 genetically deficient mice were purchased from Jackson Laboratories (Bar Harbor, Maine). All mice were housed at the Animal Research Facility at Seton Hall University. The mice were used at 6-10 weeks of age. All protocols were reviewed and approved by the Seton Hall University Ethics Committee utilizing NIH standards.

\subsubsection{Peritoneal exudate cell (PEC) isolation}

PECs were harvested from wildtype, TLR-2 deficient, or TLR-4 deficient mice and centrifuged in a refrigerated centrifuge at $4,000 \mathrm{~g}$ for 10 minutes. Following centrifugation, the interface containing PECs was resuspended in RPMI with $10 \%$ FBS, prior to enumeration. Identification and enumeration of PECs was based on the expression of surface antigens F4/80 (data not shown)

\subsubsection{Cytokine assays}

Mouse PECs or the murine monocyte cell line, RAW 267.4 cells, were cultured in the presence of our novel saccharide compound 1, diluted in PBS / 2\% DMSO, at a concentration of either 1 or $5 \mu \mathrm{g} / \mathrm{ml}$. As a positive control, cells were cultured with $10 \mu \mathrm{g} / \mathrm{ml}$ of E.coli LPS (Sigma). Supernatants were collected at designated time points and the levels of IL- 6 and TNF- $\alpha$ cytokines were measured using ELISA kits and by following vendor instructions (Biolegend).

\subsubsection{Flow cytometry blocking experiments}

PECs from wildtype, C57BL/6 mice were harvested and cultured for $20 \mathrm{~min}$ at $37{ }^{\circ} \mathrm{C}$ with varying concentrations of the saccharide compound. Following incubation, PECs were washed and stained with anti-TLR-4-PE or anti-TLR-2-PE mAbs (BD Pharmingen). The level of TLR blocking by the saccharide compound was determined by flow cytometry (MACSQuant Analyzer, Miltenyi Biotech).

\subsection{Statistical Analysis}

Statistical differences among the groups were analyzed using a one-way analysis of variances (ANOVA) or the unpaired, onetailed student t-test. GraphPad Prism 4 provided the software for the statistical analysis (San Diego, CA.).

\section{Acknowledgments}

This research was supported in part by the National Science Foundation (MRI 1337426) and the Seton Hall University Department of Biological Sciences and Department of Chemistry and Biochemistry research funds.

The authors would like to thank Emi Hanawa-Romero and Kari Wiedinger for their assistance with experiments performed in this manuscript.

\section{References and notes}

1. Petrovsky, N.; Aguilar, J. C. Immunol. Cell Biol. 2004, 82, 488496.

2. Maisonneuvea, C.; Bertholet, S.; Philpotta, D. J.; De Gregorio, E. Proc. Nat. Acad. Sci. 2014, 111, 12294-12299.

3. a) Reed, S. G.; Orr, M. T.; Fox, C. B. Nature Medicine 2013, 19(12), 1597-1608; b) Petrovsky, N.; Cooper, P. D. Expert Rev Vaccines 2011, 10(4), 523-537; c) Alving, C. R.; Peachman, K K.; Rao, M., et al. Curr. Opin. Immunol. 2012, 24, 310-315.

4. a) Cobb, B. "Glycobiology of Immune Response", Annals NYAcad. Sci. 2012, 1253, pp. 1-15. b) Marzabadi, C. H.; Franck, R. W. Chem. Eur. J. 2016, 22, 1-16, doi: 10.1002/chem.201601539

5. Janeway, C. A. Cold Spring Harb. Symp. Quant. Biol. 1989, 54(Pt 1):1-13.

6. a) Iwasaki, A.; Medzhitov, R. Science 2010, 327, 291-295; b) Iwasaki, A.; Medzhitov, R. Nature Immunol. 2004, 5(10), 987 995.

7. Liu, J. J.; Buisman-Pijlman, F.; Hutchinson, M. R. Front. Neurosci. 2014, doc:10.3389/fnins 2014.00309.

8. Peri, F.; Calabrese, V. J. Med. Chem. 2014, 57, 3612-3622.

9. Bhardwa, N.; Gnjatic, S.; Sawhney, N. B. Cancer J. 2010, 16(4), 382-391. doi:10.1097/PPO.0b013e3181eaca65

10. Dowling, J. K.; Mansell, A. Clin. \& Translat. Immunol. 2016, 5 , e85; doi:10.1038/cti.2016.22.

11. Morgan, M. J.; Liu, Z-G. Cell Res. 2011, 21, 103-115.

12. a) Park, B. S.; Song, D. H.; Kim, H. M.; et al. Nature 2009, 458,1191-1196.b) Ohto, U.; Fukase, K.; Miyake, K.; Shimizu, T. Proc. Natl. Acad. Sci. U.S.A. 2012, 109, 7421-7426.

13. Casella, C. R.; Mitchell, T. C. Cell Mol. Life Sci. 2008, 65(20), 3231-3240

14. Garcon, N.; Leo, O. Curr. Cancer Ther. Rev. 2010, 6, 126-137. 
15. Kundi, M. Expert Rev. Vaccines 2007, 6, 133-140.

16. Mato-Haro, V.; Cekic, C.; Martin, M.; et al. Science 2007, 316(5831), 1628-1632.

17. Coler, R.N.; Bertholet S.; Moutaftsi, M.; et al. PloS one. 2011, 6(1):e16333-e. doi: 10.1371/journal.pone.0016333. pmid:21298114.

18. For recent and ongoing studies see: https://clinicaltrials.gov.

19. Cook, D. N.; Pisetsky, D.S.; Schwartz, D.A. Nature Immunol. 2004, 5, 975-979.

20. Jerala, R. Int. J. Med. Microbiol. 2007, 297, 353-363.

21. H. M. Kim, B. S. Park, J.-I. Kim, S. E. Kim, J. Lee, S. C. Oh, P Enkhbayar, N. Matsushima, H. Lee, O. J. Yoo, J.-O. Lee, Cell 2007, 130, 906-917.

22. I. Dunn-Siegrist, P. Tissieres, G. Drifte, J. Bauer, S. Moutel, J. Pugin, J. Biol. Chem. 2012, 287, 16121-16131.

23. a) Geissner, A.; Pereira, C. L.; Leddermann, M.; Anish, C.; Seeberger, P. H. ACS Chem, Biol, 2016, 11, 335-344; b) Bennett, Larry G.; Bishop, Claude T. Immunochem. 1977, 14(9-10), 693-6.

24. a) Yang, F-L; Yang, Y-L; Liao, P-C; Chou, J-C.; Tsai, K.-C.; Yang, A.S; , Fuu; L., Tzu-Lung; H., P-F; Wang, J-T; et al. J. Biol. Chem. 2011, 286(24), 21041-21051.

25. Baumann, H.; Tzianabos, A. O.; Brisson, J. R.; Kasper, D. L.; Jennings, H. J. Biochem. 1992, 31(16), 4081-9.

26. Das, S. K.; Roy, N. Carbohydr. Res. 1996, 296, 275-277.

27. Zemplen, G. and Pacsu, E. Ber. Dtsch. Chem. Ges. 1929, 62, 1613-1614.

28. Dasgupta, F.; Garegg, P. J. J. Carbohydr. Chem. 1988, 7(3), 701707.
29. Parameswar, A. R.; Imamura, A.; Demchenko, A. V. From Carbohydrate Chemistry: Proven Synthetic Methods 2012, 1, 187-196.

30. Roy, S.; Chakraborty, A.; Ghosh, R. Carbohydr. Res. 2008, 343, 2523-2529.

31. Reginato, G.; Ricci, A.; Roelens, S. Scapecchi, S. J. Org. Chem. 1990, 55, 5132-5139.

32. a) Roy,S.; Sarkar, S. K.; Roy, N. Indian Journal of Chemistry-B, 2005, 137-140; b) Ziegler, T. Eckhardt, E.; Strayle, J.; Herzog, H Carbohydr Res 1994, 253, 167.

33. Corey, E. J.; Venkateswarlu, J. J. Am. Chem. Soc. 1972, 94, 61906191.

34. For example: Zeng, Y.; Ning, J.; Kong, F. Carbohydr Res. 2003, 338, 307-311.

35. van Duin, D.; Medzhitov, R.; Shaw, A. C. Trends in Immunol. 2006, 27(1), 49-54.

36. Lu, Y.C.; Yeh, W-C.; Ohashi, P. S. Cytokine 2008, 42, 145-151.

37. Van Gool, S.; Vandenberghe, P.; de Boer, M.; Ceuppens, J. L. Immunol. Rev. 1996, 153, 47-83.

38. Cook, D. N.; Pisetsky, D.S.; Schwartz, D.A. Nature Immunol. 2004, 5, 975-979.

39. Huang, Q-Q.; Pope, R. M. Curr. Rheumatol. Rep. 2009, 11, $357-$ 364.

40. Aryan, Z.; Holgate, S. T.; Radzioch, D.; et al. Int. Arch. Allergy Immunol. 2014, 164, 46-63.

41. Alfonso-Loeches, S.; Pascual-Lucas, M.; Blanco, A. M.; et al. J. Neuroscience 2010, 30(24), 8285-8295. 


\section{Graphical Abstract}

To create your abstract, type over the instructions in the template box below.

Fonts or abstract dimensions should not be changed or altered.

Synthesis and immunological evaluation of a

Leave this area blank for abstract info.

low molecular weight saccharide with TLR-4

agonist activity

Vikram Basava, Heather Romlein, Constantine Bitsaktsis and Cecilia H. Marzabadi

Seton Hall University 